actions is partly responsible for the delay in world recovery. Previous excessive borrowing, impoverishment of borrowers and the excessive fall in prices have led to much partial or complote default. For the immediate future, no purely financial measures are deemed sufficient as a means of reviving the normal flow of capital. The inmediate need is to restore conditions of political security, since only in this way can confidence be resuscitated. For the remoter future, various methods for the control of international capital movements aro recommended and it is urged that these should be considered without delay.

\section{Electric Power Supply in Great Britain}

IN the Electrical Review for June 30 an account is given of the opening of the World Power Conference at Copenhagen on June 26. At a technical meeting an important paper was read by $\mathrm{H}$. Hobson, $\mathrm{F}$. Forrest and C. D. Taite giving a survey of the industrial electric power supply in Groat Britain. In Germany, the United States and France, the percentage of the working population engaged in manufacturing industries is $59 \cdot 8,56 \cdot 2$ and $46 \cdot 8$ respectively. In Great Britain tho corresponding figure is 73.5 , the power supply being of predominant importance. The want of co-ordination and piecemeal development of public electricity supply has in the past led many industrialists to manufacture their own electric power. When the industrial output is low, the overhead charges of these private generuting stations have proved a heavy burden on industry. Figures are given showing the great increase in the horse power per worker employed in the manufacturing industries which has recently occurred. The English 'grid' not only accelerates the operation of the various influences making for economy but also introduces new factors in the economics of public eloctricity supply. The generation of energy is concentrated in a limited number of inter-connected stations. This makes possible an increase in tho thermal efficiency of generation and the more economic employment of capital and labour. In 1931 the average fuel consumption at stations to bo closed down was $2 \cdot 19 \mathrm{lb}$. per kilowatt hour. At the selected stations with an output exceeding 100 million kwh. per annum it was $1.54 \mathrm{lb}$. A considerable economy of fuel has thus been effected. Private industrial plants are rapidly becoming obsolescent. In some cases the supply authorities are taking over the responsibility of operating the private plant during the remainder of its life before a public supply is installed.

\section{Annual Meeting of 'Dechema'}

A Number of technical papers were read at the Dechema (German Chemical Apparatus Society) annual meeting at Würzburg on Juno 8-9, among which reference may be made to a few. Dr. W. J. Müller of Vienna, who is seeking a logical method of teaching chemical engineering, whilst approving tho American plan of sub-division of the mechanical side according to the operations which are usually performed, for example, filtration, distillation, drying, etc., makes the suggestion that chemical technology should bo taught according to a scheme based on the nature of the phases concerned in the reactions, for oxample, solid and solid, solid and liquid, solid and gas, etc., seven in all of such phase combinations being possible. His new method is elaborated in his lecture, the chief claim for it being that it distinguishes between what is general and what is exceptional in chemical technology. The development and position of the safety glass industry was described by F. Ohl of Darmstadt ; such glass has now como gencrally into use for a great variety of purposes, while its munufacture has reached a high standard. E. Risemann of Frankfurt brought up to date the story of the use of active curbon in solvent recovery and for the scrubbing of gases. In technical work, nearly complete recovery of an organic solvent, even from very dilute air mixtures, is attained; whilst the plant has been simplified and cheapened, the operating cost being less than $\frac{1}{2} d$. per kilo recovered. Practically twice as much light petrol is scrubbed out of a gas of the same composition at the well head as a few yeurs ago, plants yielding as much as 100 tons per day being in operation. For the scrubbing of a benzol of high quality out of town gas, a new carbon has been brought into use of which very much less is required. The large installations in London and Paris are working well and another is under construction at Budapest.

\section{British Postgraduate Medical School}

ON July 17 at 4 p.m. the Right Hon. Neville Chamberlain will lay the foundation stone of the British Postgraduate Medical School buildings at the L.C.C. Hospital, Ducane Road, London, W.6, thus marking a further stage in bringing into practical operation the scheme recommended by the Post. graduate Medical Education Committee appointed in 1925. The scheme is founded upon the association of the now medical school with a public hospital administered by the London County Council. 'The Government has agreed to contribute a maximum of $£ 100,000$ for the building and equipment of the School, and the London County Council has agreed to incur an equivalent expenditure on such developments and adaptations of the Hospital as are found to be necessary at the present time in view of its forthcoming association with the School. 'The Government has undertaken to provide in due course for annual grants towards the maintenance of the School as a recognised School of the University of London. The new postgraduate teaching hospital will doubtless attract medical men to London from all parts of the world, and especially from the British Dominions and Colonies overseas, and will serve to establish London as one of the chief centres in the world for medical training and research.

\section{Announcements}

Sir Robert A. Havfield, Bt., has been awarded the decoration of Commendatore of the Order of the Crown of Italy, "in recognition of general scientific work". 